\begin{tabular}{l} 
The development of a complex bakery \\
improver "Freshness CDP SUPER" (Ukra- \\
ine) to slow down the staling of prod- \\
ucts developed for accelerated technologies \\
is urgent. It contains nutritional supple- \\
ments with GRAS status. Whey protein \\
concentrate "CDP-UV-65" was chosen as a \\
functional basis. The active part contains \\
the enzyme preparation Novamil 1500MG, \\
maltodextrin, defatted sunflower lecithin, \\
carboxymethyl cellulose, apple pectin, dry \\
wheat gluten and ascorbic acid. It is proved \\
that with rational dosage of the developed \\
complex bakery improver in the amount of \\
$1.5 \%$ to the flour mass, the bread produc- \\
tion process is reduced by 180 minutes. \\
It has been established that the bread \\
"Milk Freshness", the recipe of which \\
includes the developed improver, is char- \\
acterized by a higher specific volume \\
by $10.1 \%$ in comparison with the con- \\
trol, porosity, and better shape stability of \\
hearth products. \\
It has been proven that products with \\
the addition of the Freshness CDP SUPER \\
complex bakery improver retain freshness \\
longer, which is confirmed by a $47 \%$ great- \\
er total crumb deformation compared to the \\
control. \\
The inhibition of staling in bread "Milk \\
Freshness" occurs due to the accumulation \\
of dextrin by $27.1 \%$ compared with the con- \\
trol. Thus, the total content of dextrins in \\
wheat bread is $1.918 \%$ to DS, and in Milk \\
Freshness bread- $2.438 \%$ to DS. \\
The research results prove the expedi- \\
ency of using the complex bakery improv- \\
er "Freshness CDP SUPER" in the technol- \\
ogy of wheat bread in order to extend the \\
preservation period of its freshness up to \\
72 hours in unpackaged form \\
Keywords: complex bakery improver, \\
wheat bread, staling, dextrin, functional \\
base, active part \\
\hline
\end{tabular}

UDC 664.663 .9

DOI: $10.15587 / 1729-4061.2020 .214934$

\title{
DEVELOPING AN IMPROVER OF TARGETED ACTION FOR THE PROLONGED FRESHNESS OF BREAD MADE FROM WHEAT FLOUR
}

\author{
O. Bily k \\ $\mathrm{PhD}$, Associate Professor* \\ E-mail: bilyklena@gmail.com \\ O. Koch u be i - L y t v y ne nko \\ $\mathrm{PhD}$, Associate Professor* \\ E-mail: okolit@email.ua \\ Y u . B ond a renko \\ $\mathrm{PhD}$, Associate Professor* \\ E-mail: bjuly@ukr.net \\ T. V a s ylchenko \\ Head of Laboratory \\ Laboratory of Production Workshops No. 7-8 \\ LLC KYIV KHLIB \\ Boryspilska str., 24, Kyiv, Ukraine, 01601 \\ E-mail: tvasil4enko@mail.ru \\ A. Pukhliak \\ $\mathrm{PhD}$, Associate Professor \\ Department of Technology Milk and Dairy Products** \\ E-mail: agpukh@i.ua \\ *Department of Bakery and \\ Confectionary Goods Technology** \\ **National University of Food Technologies \\ Volodymyrska str., 68, Kyiv, Ukraine, 01601
}

\section{Introduction}

The production of bakery products for long-term storage is the main priority of the bakery industry to provide the population with products in the regions of military conflicts, crisis and emergency situations, as well as the contingent, for social services $[1,2]$. Due to the economic situation, the production of bakery products is increasingly moving to accelerated methods. The production of bread with a long shelf life for accelerated technologies is accompanied by the problem of rapid passage of the processes associated with staling products [3].

The use of complex bakery improvers allows to target the main biopolymers, thus regulating the properties of the dough, the course of the technological process, the quality of bakery products and their shelf life [4].

There is a lot of competition in the market for complex bakery improvers, since their range is very diverse, depending on the direction of their action, different pricing policy and raw material base [5].

Complex bakery improvers consist of a functional base and an active part. Flour, extruded flour, starch, dry wheat gluten and others are used as a functional base. The active part includes gluten oxidizing and reducing agents, enzymes, emulsifiers and various food additives or ingredients with specific effects, namely, inhibitors of the development of mold and pathogens of potato disease. The components of the complex bakery improver are selected according to its 
directional action, activity and synergistic action among themselves [6].

Since baked goods are a product of daily consumption, these products must be made safe. Therefore, it is advisable to use food additives with the GRAS status, that is, safe when developing a complex bakery improver. And it is also necessary that the optimal dosage of the complex bakery improver does not exceed $2 \%$ by weight of flour based on organic production, in today's conditions it is a priority [7].

So, it is urgent to develop a complex bakery improver, which will improve the quality of products, increase their freshness using accelerated technology. When developing a recipe for a complex bakery improver, non-traditional raw materials of animal or vegetable origin should be chosen as a functional basis. It is also advisable to use in its development food additives that have the GRAS status and so that its optimal dosage does not exceed $2 \%$ by weight of flour.

\section{Literature review and problem statement}

When developing complex bakery improvers, scientists and commercial organizations are governed by basic rules this is the choice of the functional basis and the components of the active part. The majority of people choose traditional raw materials for bakery products as a functional basis; food additives are the active part.

Bakery products are an everyday human food product, therefore it is recommended to produce them from safe raw materials and use food additives with GRAS status. Generally Recognized As Safe (GRAS) is a regulatory designation first introduced by the US Food and Drug Administration (FDA) as part of 1985 GRAS status is given to food ingredients that can't harm the human body [8]. These food additives include carboxymethyl cellulose, maltodextrin, ascorbic acid, lecithin, and enzyme preparations [9].

When developing complex bakery improvers, most attention is paid to the choice of a functional base, which should have a technological function for both the improver and the bread.

To improve the quality of bread, a complex bakery improver was developed [10] in which dry wheat gluten was selected as a functional basis. The active part contains ascorbic acid, enzyme preparations of amylolytic and pentosanase activity, and an emulsifier. The optimal dosage of the developed complex bakery improver is $0.5 \%$ to the flour mass, but to increase the intensification of the technological process, it is necessary to increase its dosage, which will lead to an increase in the cost of bread. Therefore, it is advisable to continue the search for alternative ingredients as a functional basis in the formulation of complex bakery improvers.

In the case of processing flour with low baking properties, a complex baking improver has been developed [11], in which the use of pumpkin flour is justified as a functional basis. The influence of pumpkin flour on the baking properties of flour, the vital activity of yeast cells and the quality of bread has been established. The active part of the complex bakery improver includes ascorbic acid, calcium phosphate, ammonium sulfate. This improver contains in its composition chemical substances that do not have the GRAS status but do not lead to an intensification of the technological process of bread production. It is expedient to develop bak- ery improvers, which will contain food additives that will intensify the technological process and have the GRAS status.

The work [12] provides information on a complex bakery improver in which buckwheat malt is selected as a functional base, and calcium phosphate, ammonium sulphate as an active part. This improver is designed for flour with elasticity ranging from 50 to 70 units of device. The main purpose of the development of this improver was to increase the nutritional value and quality indicators of wheat bread, but chemicals that do not have the GRAS status were selected as an active part.

The work [12] provides information on a complex bakery improver in which buckwheat malt is selected as a functional base, and calcium phosphate, ammonium sulphate as an active part. This improver is designed for flour in which the IDCis in the range from 50 to 70 units of device. The main purpose of the development of this improver was to increase the nutritional value and quality indicators of wheat bread, but chemicals that do not have the GRAS status were selected as an active part.

The aim of work [13] was to determine the optimal dosage of the developed complex bakery improver in the production of bread from wheat flour. The complex bakery improver consisted of lecithin, ascorbic acid and -amylase. The article shows the positive effect of the developed improver on the consumer characteristics of bread, namely, freshness, but it is not shown how the use of amylolytic enzymes will affect the intensification of the technological process. Moreover, it is not clear which raw material was chosen as the functional basis.

Emulsifiers are often included in the complex bakery improver. The work [14] shows the feasibility of using emulsifiers in the composition of complex bakery improvers, but at the same time, an extension of the technological cycle is noted. It is substantiated in the work that it is better to use sucrose ether or phospholipids (lecithin) to prolong the freshness of bakery products. Therefore, in this direction it is possible to expand the range of targeted improvers through the use of phospholipids from various raw materials.

It is recommended to add additional proteins to prolong the freshness. The work [15] investigated the effect of dry wheat gluten on the staling of bakery products that were stored for 7 days. It was found that in the case of adding $15 \%$ of dry wheat gluten to the mass of flour, the bread retained a great high softness and elasticity. However, the work did not show a synergistic effect of dry wheat gluten with food additives. The use of dry wheat gluten in the amount of $15 \%$ by weight of flour leads to an increase in the cost of bakery products. Therefore, it is more effective to develop an improver, with which dry wheat gluten will be introduced to a lesser extent, due to the use of food additives.

The food additive carboxymethyl cellulose is characterized by a high water-claying capacity, which is positive in prolonging the freshness of baked goods. The work [16] established a positive effect of using carboxymethyl cellulose to prolong the freshness of bakery products. The optimal dosage is $0.5 \%$ by weight of flour. The work does not indicate recommendations on the possible use of carboxymethyl cellulose as part of the active part of complex bakery improvers.

The work [17] proves the positive effect of $\alpha$-amylase on slowing down the process of starch retrogradation during storage of bakery products. Thus, the use of $\alpha$-amylase in the technology of bakery products results in an extension 
of freshness up to 12 days. These research results are the basis for the continued use of $\alpha$-amylase in complex bakery improvers.

Scientific work [18] found that apple pectin with a high degree of substitution of methoxyl groups due to its high water-holding capacity is an effective hydrocolloid for improving the consumer properties of bakery products. But the work does not indicate how the introduction of apple pectin affects the conduct of the technological process and in what optimal dosages to use in the formulations of complex bakery improvers. Therefore, it is advisable to continue research in this direction.

In [19], it is proved that maltodextrin is an effective water-retaining agent in the production of bakery products. It increases the degree of moisture content and reduces the rate of starch retrogradation. The work does not show which dosing is optimal for bread made from wheat flour, which requires further research.

The analysis of the literature has shown that the development of a composition of a complex bakery improver with a directed action, namely, for intensifying the technological process and lengthening the freshness of bread made from wheat flour, is relevant. It is also necessary to pay attention that scientists choose only plant raw materials as a functional basis, not paying attention to whey powder, whey protein concentrate, milk powder. So, it is relevant to develop a complex bakery improver with a directed action, in which raw materials from milk processing products are used as a functional basis, and in the active part, use food additives with the GRAS status.

\section{The aim and objectives of research}

The aim of research is to develop a complex bakery improver to prolong the freshness of bread made using accelerated technologies. lated:

To achieve this aim, the following objectives are formu-

- select raw materials and develop a recipe for a complex bakery improver "Freshness CDP SUPER" directed action for bread made from wheat flour;

- establish the influence of rational dosing of the complex bakery improver "Freshness CDP SUPER" on the quality of wheat bread made using accelerated technologies;

- study the effect of the complex bakery improver "Freshness CDP SUPER" on the quality indicators of wheat flour bread during 72 hours of storage unpacked.

\section{Materials and methods of research on the development and influence of a complex bakery improver on the quality of bread}

\section{1. objects and materials used in the experiment}

As a functional basis for the complex bakery improver "Freshness CDP SUPER" was selected whey protein dry concentrate "CDP-UF-65" (CDP) of the Ukrainian company "Tekhmolprom" LLC. CDP - whey protein, which is a by-product of the production of both rennet cheeses and cottage cheese, which is obtained using membrane methods of whey separation and subsequent drying.

As an active part of the complex bakery improver "Freshness CDP SUPER" were selected:
- enzyme preparation Novamil 1500MG of the Danish company "Novozymes";

- dry wheat gluten of the Finnish company "Leipurin";

- carboxymethyl cellulose of the Ukrainian company

"Himpostach";

- apple pectin and maltodextrin made in Poland;

- skimmed lecithin from sunflower produced by the Ukrainian firm "BIOLER";

- ascorbic acid produced in China.

To establish the quantitative content of each component of the improver and the effect of the developed improver on the quality of products, bread was baked from wheat flour according to the recipe given in Table 1 .

Table 1

Wheat flour bread recipe

\begin{tabular}{|c|c|}
\hline \multirow{2}{*}{ Recipe components } & Quantity, kg \\
\cline { 2 - 2 } & Wheat bread (control) \\
\hline Wheat flour of the first grade & 100 \\
\hline Pressed bakery yeast & 3.0 \\
\hline Table salt & 1.5 \\
\hline
\end{tabular}

The technological process for a control sample of wheat bread was carried out in a safe way, and in the case of adding an improver - accelerated with the exclusion of the fermentation process.

4. 2. Methods of research of the quality of wheat bread with a complex bakery improver

To study the indicators of the technological process, biochemical, physicochemical changes in the dough and quality indicators of bread, laboratory baked goods were carried out. The dough was kneaded in a safe way with a humidity of $44.5 \%$. The dough was kneaded in a two-speed dough mixer Escher (Italy). The dough was processed manually, the dough pieces were proofed in a thermostat at a temperature of $(38 \pm 2){ }^{\circ} \mathrm{C}$ and relative humidity $(78 \pm 2) \%$ until cooked. The products were baked in Sveba-Dahlen cabinet ovens (Italy) at a temperature of $220 \ldots 240{ }^{\circ} \mathrm{C}$.

The quality of the bread was assessed by its physicochemical (specific volume, dimensional stability, structural and mechanical properties of the crumb) and organoleptic indicators (appearance, condition of the crust surface, structure of porosity, taste, odor) [20].

Based on the results of organoleptic and physicochemical evaluation of finished products, a complex quality indicator was calculated. The Composite Quality Score is the total number of points a prototype receives when it is analyzed. To calculate it, each product was evaluated according to the following indicators:

- specific volume;

- correctness of the form;

- crust color;

- staling after 72 hours;

- condition of the crust surface;

- crumb color;

- porosity structure;

- dimensional stability of hearth bread;

- rheological properties of the crumb;

- bread aroma;

- bread taste;

- crumb chewiness. 
The values obtained were evaluated on a five-point scale, taking into account the weighting coefficient, which was established for each indicator by the method of expert assessment.

That is, the number of points provided to the indicator was multiplied by the weighting factor. Then the sum of the obtained values was found. The more points a sample receives as a result of the calculation, the better its quality indicators [20]. The expert commission included seven candidates of technical sciences, three applicants for a Doctor of Philosophy and 15 applicants for higher education in the specialty "Food Technologies".

The duration of the freshness preservation of the products was studied with a change in the structural and mechanical properties of the crumb. Determined its total deformation after 48 hours of storage on AP 4/1 penetrometers ("Finemass" (Germany)) [20].

The staleness degree of products was also investigated for the crumbling. Crumbling was determined by the amount of crumbs formed due to friction of two pieces of bread crumb weighing $5 \mathrm{~g}$, cut in the shape of a parallelepiped, with shaking for 5 minutes on a vibrating shaker IKA HS 501 digital (IKA®-Werke GmbH \& Co. KG, Germany). Crumbling was expressed as the ratio of the mass of crumbs to the mass of a sample of bread in percent [21].

Microscopic examination of bakery products was carried out after 72 hours of storage. The samples were stored unpacked at a temperature of $(20 \pm 0){ }^{\circ} \mathrm{C}$. The samples were prepared by freezing, freeze drying, and carbon spraying in a vacuum chamber on a piece of the dried sample. The samples were examined using a scanning electron microscope IEOLJSMM-200 (Japan) at a magnification of 1000 times and the most visible areas were photographed.

The content of dextrins was determined by the method of their mass fraction, based on the ability of dextrins to precipitate at various concentrations of ethyl alcohol in solution. The test samples are inactivated with enzymes to free the sample from water-soluble carbohydrates and fermented sugars for their better removal. Dextrins were precipitated with alcohol solutions of various concentrations. Further dissolution of the withdrawn dextrins was carried out with water, and hydrolysis with $2 \%$ hydrochloric acid solution. Determination of the amount of glucose in the hydrolyzate of dextrins of various molecular weights was carried out according to the method of Wiltetter and Schudl. On the basis of a certain content of dextrins, the mass fraction of dextrins is determined by fractions depending on the mass fraction of dextrins by different concentrations of ethyl alcohol [21].

Determination of extraneous and harmful microflora in finished products was determined by standard methods [22].

The results of experimental studies were subjected to statistical processing implemented using standard Microsoft Office software packages.

\section{Research results of studies of the quality of bakery products with the addition of a complex bakery improver}

\subsection{Development of a recipe for a complex bakery} improver "Freshness CDP SUPER"

When developing the recipe for the complex bakery improver "Freshness CDP SUPER", the functional main was the whey protein concentrate dry "CDP-UV-65" (CDP).
Since the quality and the nutritional value of bread depends on the type of composition and the properties of the components used, the organoleptic and physicochemical indicators of the whey protein concentrate dry "CDP-UV-65" are established, Table 2.

Table 2

Organoleptic, physicochemical and microbiological CDP indicators, $n=3, p \leq 0.95$

\begin{tabular}{|c|c|}
\hline The name of indicators & CDP \\
\hline \multicolumn{2}{|l|}{ Organoleptic characteristics } \\
\hline appearance & $\begin{array}{c}\text { Homogeneous fine } \\
\text { dry powder }\end{array}$ \\
\hline Taste and smell & $\begin{array}{l}\text { Peculiar to pas- } \\
\text { teurized milk whey, } \\
\text { without foreign } \\
\text { tastes and odors }\end{array}$ \\
\hline Colour & White to cream \\
\hline \multicolumn{2}{|l|}{ Physicochemical indicator } \\
\hline Mass fraction of dry substances, $\%$ & 95.4 \\
\hline Mass fraction of protein, $\%$ & 66.0 \\
\hline Mass fraction of fat, $\%$ & 5.9 \\
\hline Mass fraction of carbohydrates (lactose), $\%$ & 22.0 \\
\hline $\begin{array}{c}\text { Mineral substances, mg } \\
\text { calcium }\end{array}$ & 612 \\
\hline phosphorus & 491 \\
\hline potassium & 1210 \\
\hline magnesium & 86 \\
\hline Iron & 0.1 \\
\hline Acidity, ${ }^{\circ} \mathrm{T}$ & 21.0 \\
\hline Solubility index, $\mathrm{cm}^{3}$ & 0.2 \\
\hline Relative dissolution rate, $\%$ & 41.0 \\
\hline $\begin{array}{l}\text { Caking degree, \%, per sieve pore size } \\
250 \mathrm{~nm}\end{array}$ & 2.3 \\
\hline Whiteness, cu & 94.1 \\
\hline \multicolumn{2}{|l|}{ microbiological indicators } \\
\hline QMAFAnM quantity, CFU/g & 21500 \\
\hline BGKP (coliform) in $0.1 \mathrm{~g}$ & absent \\
\hline
\end{tabular}

The assessment of the CDP chemical composition shows that its use in the technology of wheat bread will enrich the finished products with proteins of animal origin, minerals such as $\mathrm{Ca}, \mathrm{F}, \mathrm{K}, \mathrm{Mg}$.

It has been established that the CDP acidity is $21.0^{\circ} \mathrm{T}$, which will not affect the technological processes of the production of bread from wheat flour and its quality. It is also found that CDP in terms of whiteness corresponds to the whiteness of premium wheat flour, will not lead to darkening of finished products. One of the main characteristics of complex bakery improvers is non-clumping. It is found that CDP has a caking degree of less than $3.0 \%$, that is, a low tendency to form lumps, which makes it possible to use it in the production of complex bakery improvers.

To develop a recipe for a complex bakery improver "Freshness CDP SUPER", the optimal dosage of each ingredient in the dough for making wheat bread was determined according to the complex quality indicator. The dosage limits were chosen according to the manufacturer's recommendations.

The data obtained from the calculation of the integrated quality indicator and the choice of the optimal dosage of ingredients in the improver formulation are given in Table 3. 
Table 3

Determination of the optimal dosage of prescription components of the complex bakery improver "Freshness CDP SUPER" according to the complex quality indicator, $n=3, p \leq 0.95$

\begin{tabular}{|c|c|c|c|c|c|c|}
\hline Indicator & $\begin{array}{l}\text { Control with- } \\
\text { out additives }\end{array}$ & \multicolumn{5}{|c|}{ Dosage, \% by weight of flour } \\
\hline \multirow{3}{*}{$\begin{array}{l}\text { Comprehen- } \\
\text { sive quality } \\
\text { indicator }\end{array}$} & \multirow{3}{*}{84.6} & \multicolumn{5}{|c|}{$\mathrm{CDP}$} \\
\hline & & 1 & 2 & 3 & 4 & 5 \\
\hline & & 85.1 & 86.4 & 88.2 & 88.1 & 87.4 \\
\hline \multirow{3}{*}{$\begin{array}{l}\text { Comprehen- } \\
\text { sive quality } \\
\text { indicator }\end{array}$} & \multirow{3}{*}{84.6} & \multicolumn{5}{|c|}{$\begin{array}{l}\text { Enzyme preparation } \\
\text { Novamil } 1500 \mathrm{MG}\end{array}$} \\
\hline & & 0.006 & 0.012 & 0.018 & 0.024 & 0.030 \\
\hline & & 85.7 & 86.3 & 88.4 & 90.1 & 90.1 \\
\hline \multirow{3}{*}{$\begin{array}{l}\text { Comprehen- } \\
\text { sive quality } \\
\text { indicator }\end{array}$} & \multirow{3}{*}{84.6} & \multicolumn{5}{|c|}{ Dry wheat gluten } \\
\hline & & 0.2 & 0.3 & 0.4 & 0.5 & 0.6 \\
\hline & & 84.9 & 85.7 & 86.1 & 87.2 & 87.4 \\
\hline \multirow{3}{*}{$\begin{array}{l}\text { Comprehen- } \\
\text { sive quality } \\
\text { indicator }\end{array}$} & \multirow{3}{*}{84.6} & \multicolumn{5}{|c|}{ Carboxymethyl cellulose } \\
\hline & & 0.2 & 0.3 & 0.4 & 0.5 & 0.6 \\
\hline & & 84.8 & 85.1 & 85.8 & 86.3 & 86.4 \\
\hline \multirow{3}{*}{$\begin{array}{l}\text { Comprehen- } \\
\text { sive quality } \\
\text { indicator }\end{array}$} & \multirow{3}{*}{84,6} & \multicolumn{5}{|c|}{ Apple pectin } \\
\hline & & 0.03 & 0.06 & 0.09 & 0.12 & 0.15 \\
\hline & & 84.8 & 85.3 & 85.9 & 86.2 & 86.2 \\
\hline \multirow{3}{*}{$\begin{array}{l}\text { Comprehen- } \\
\text { sive quality } \\
\text { indicator }\end{array}$} & \multirow{3}{*}{84.6} & \multicolumn{5}{|c|}{ Maltodextrin } \\
\hline & & 0.03 & 0.06 & 0.09 & 0.12 & 0.15 \\
\hline & & 85.1 & 85.6 & 86.1 & 86.8 & 86.9 \\
\hline \multirow{3}{*}{$\begin{array}{l}\text { Comprehen- } \\
\text { sive quality } \\
\text { indicator }\end{array}$} & \multirow{3}{*}{84.6} & \multicolumn{5}{|c|}{ Lecithin } \\
\hline & & 0.12 & 0.18 & 0.24 & 0.30 & 0.36 \\
\hline & & 85.3 & 85.9 & 86.7 & 87.4 & 87.6 \\
\hline \multirow{3}{*}{$\begin{array}{l}\text { Comprehen- } \\
\text { sive quality } \\
\text { indicator }\end{array}$} & \multirow{3}{*}{84.6} & \multicolumn{5}{|c|}{ Vitamin C } \\
\hline & & 0.004 & 0.006 & 0.008 & 0.010 & 0.012 \\
\hline & & 84.8 & 85.2 & 85.4 & 85.8 & 86.2 \\
\hline
\end{tabular}

According to the complex quality indicator, it has been established that the optimal dosage of the functional base, namely the CDP, is $3 \%$ to the flour mass. According to the research results, it is found that the optimal dosage of food additives and food ingredients in the active part are:

- enzyme preparation Novamil 1500 MG - 0.024;

- dry wheat gluten - 0.6;

- carboxymethyl cellulose -0.6 ;

- apple pectin - 0.12;

- maltodextrin -0.12 ;

- lecithin - 0.36;

- ascorbic acid $-0.012 \%$ by weight of flour.

Manufacturers and scientists recommend that when formulating a complex bakery improver, the optimal dosage of food additives and food ingredients in the active part should be halved. This is due to their synergistic action when applied together $[7,10]$.
As a result of the research, formulations of the complex bakery improver "Freshness CDP SUPER" have been developed, which are given in Table 4.

Table 4

\section{Recipe for complex bakery improver "Freshness CDP SUPER"}

\begin{tabular}{|c|c|c|}
\hline Raw material & $\begin{array}{c}\text { Optimal dosage, } \% \\
\text { to the mass of flour } \\
\text { in the recipe for } \\
\text { wheat bread }\end{array}$ & $\begin{array}{c}\text { Raw material con- } \\
\text { sumption, \% to the } \\
\text { CDP mass }\end{array}$ \\
\hline CDP & 3.0 & 100.0 \\
\hline $\begin{array}{c}\text { Enzyme preparation } \\
\text { Novamil 1500 MG }\end{array}$ & 0.012 & 0.4 \\
\hline Dry wheat gluten & 0.3 & 10 \\
\hline $\begin{array}{c}\text { Carboxymethyl } \\
\text { cellulose }\end{array}$ & 0.3 & 10 \\
\hline Apple pectin & 0.06 & 2 \\
\hline Maltodextrin & 0.06 & 2 \\
\hline Lecithin & 0.18 & 6 \\
\hline Vitamin C & 0.006 & 0.2 \\
\hline
\end{tabular}

Thus, a recipe for a complex bakery improver "Freshness CDP SUPER" has been developed, which is designed to intensify the technological process and lengthen the freshness of bread made from wheat flour, which includes food additives with the GRAS status.

\section{2. Study of the effect of the developed complex bak-} ery improver on the bread quality

To confirm the feasibility of the developed improver, let's study its effect on the quality of bread made from wheat flour produced in a safe way. For this, a test laboratory baking of wheat bread (control sample) and bread to which $1.5 \%$ to the mass of flour of the complex bakery improver "Freshness CDP SUPER" introduced into the recipe was carried out. The technological process for the control sample was carried out in a safe way - the duration of fermentation was $210 \mathrm{~min}$, for the developed sample, instead of the fermentation process, a curing process was carried out, which lasted $30 \mathrm{~min}$. The research results are shown in Table 5.

As the results of Table 5, despite the removal of the fermentation process in the manufacture of bread, in the case of using the complex bakery improver "Freshness CDP SUPER", it helps to improve the organoleptic and physicochemical indicators of quality. When using the improver, the specific volume of products increases from $305 \mathrm{~cm}^{3} / 100 \mathrm{~g}$ to $336 \mathrm{~cm}^{3} / 100 \mathrm{~g}$ by $10.1 \%$, while the porosity increases and the dimensional stability of the finished products improves. General deformation after 72 hours of storage of the product crumb from the improver 56 units of penetrometer, and control 38 units of penetrometer, that is, $47 \%$ more. The developed improver helps to lengthen the freshness of bakery products by $17.0 \%$. That is, in the case of using the developed complex bakery improver "Freshness CDP SUPER", it is possible to reduce the technological process by three times and at the same time obtain high-quality products. 
Table 5

Influence of the complex bakery improver "Freshness CDP SUPER" on the technological process and product quality, $n=3, p \leq 0.95$

\begin{tabular}{|c|c|c|}
\hline \multirow{2}{*}{ Indicators } & \multicolumn{2}{|c|}{ Test samples } \\
\hline & Wheat bread (without additives) & Wheat bread from improver \\
\hline \multicolumn{3}{|c|}{ Dough } \\
\hline Moisture content, \% & \multicolumn{2}{|c|}{44.5} \\
\hline Fermentation duration, min & 210 & - \\
\hline Duration of soaking, min & - & 30 \\
\hline Proofing time, min & 40 & 40 \\
\hline \multicolumn{3}{|c|}{ Finished goods } \\
\hline Organoleptic indicators: & - & - \\
\hline Correct form & conforms to the form & conforms to the form \\
\hline Crust color & light coloured & Golden to brown \\
\hline Crust surface condition & $\begin{array}{l}\text { Sufficiently smooth, single small bubbles, } \\
\text { barely noticeable small short cracks and } \\
\text { explosions, glossy }\end{array}$ & $\begin{array}{l}\text { Flawlessly smooth, bubble-free, crack-free, } \\
\text { puff-free, glossy }\end{array}$ \\
\hline Porosity structure & \multicolumn{2}{|c|}{ Times are small, thin-walled and medium, distributed fairly evenly } \\
\hline Flavor & \multicolumn{2}{|c|}{ Intensely expressed, typical of bread } \\
\hline Taste & \multicolumn{2}{|c|}{ Intensely expressed, typical of bread } \\
\hline Specific volume, $\mathrm{cm}^{3} / 100 \mathrm{~g}$ & 305 & 336 \\
\hline Form stability, h/d & 0.35 & 0.42 \\
\hline Porosity, \% & 68 & 78 \\
\hline Acidity, hail & 1.8 & 1.8 \\
\hline General crumb deformation, units penetrometer & - & - \\
\hline after $4 \mathrm{~h}$ & 92 & 96 \\
\hline $72 \mathrm{~h}$ & 38 & 56 \\
\hline Freshness preservation, \% & 41 & 58 \\
\hline
\end{tabular}

5. 3. Influence of a complex bakery improver on the preservation of freshness of products

During storage of bread, a decrease in its quality indicators is observed, associated with the process of staleness and drying out. The bread becomes hard, crumbly, its elasticity decreases, taste and aroma are lost.

During storage, the physical and mechanical properties of the crumb change, the walls of the pores lose their strength, which is accompanied by an increase in crumb formation. Therefore, it was expedient to investigate the effect of the developed improver on the product's crumbling during storage (Fig. 1).

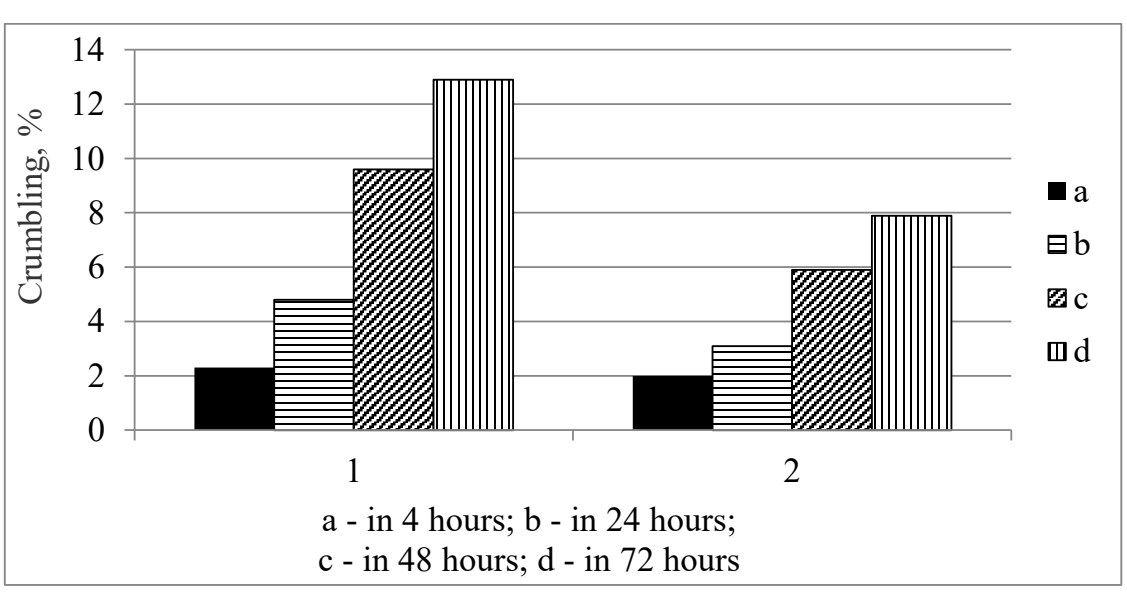

Fig. 1. Crumbling, \%: 1 - wheat bread; 2 - wheat bread with improver
The research results indicate that the crumbling value decreases in the case of using the Freshness CDP compared to the control - by $50 \ldots 54 \%$ under the condition of storage for 24 and 48 hours and by $57 \%$ - in the case of storage for 72 hours.

To substantiate the decrease in crumbling, a comparative analysis of the microstructure of the crumb of research products after 72 hours of storage was carried out. The research results are shown in Fig. 2.

The structure of bakery products is characterized by the presence of swollen starch grains covered with interporous walls, forming a spongy frame. In wheat bread, it is clearly visible that the spongy frame does not completely envelop the swollen starch grains, as a result of which layers of air are formed. This indicates that during storage, the volume of starch grains decreases due to the formation of the crystalline structure of starch. In bread with improver, the crumb after 72 hours of storage consists of a solid mass of proteins coagulated during baking, in the middle of which there are swollen, partially gelatinized starch grains. That is, fewer air layers are observed.

During the maturation of the dough and during the baking of dough pieces, the starch of the flour decomposes. Under the action of the 
flour's own amylolytic enzymes and the attached amylolytic enzymes, if added, starch decomposes with the formation of various dextrins.

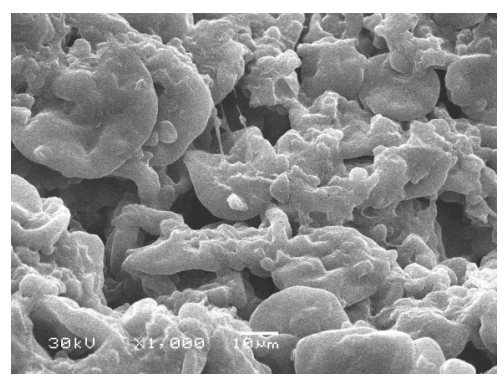

$a$

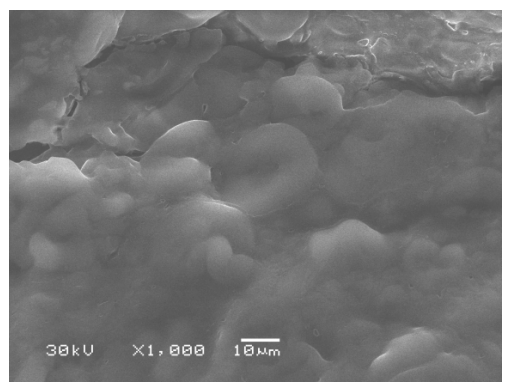

$b$

Fig. 2. Crumb microstructure of the prototypes of finished products after 72 hours of storage: $a$ - wheat bread (without additives); $b$ - wheat bread with an improver

It is known from the literature that the presence of more dextrins in baked goods prolongs their freshness. With the developed improver, an additional enzyme preparation with active maltogenic $\alpha$-amylase and maltodextrin are added to the dough; therefore, it was advisable to establish the amount of dextrins in the test samples of bakery products after 4 hours of cooling. The research results are presented in Table 6.

Table 6

Dextrin content in bakery products, $n=3, p \leq 0.95$

\begin{tabular}{|c|c|c|c|c|}
\hline \multirow{2}{*}{$\begin{array}{l}\text { Samples } \\
\text { of bakery } \\
\text { products }\end{array}$} & \multicolumn{3}{|c|}{$\begin{array}{c}\text { Dextrins content by fractions, \% to } \\
\text { DS * }\end{array}$} & \multirow{2}{*}{$\begin{array}{c}\text { Total } \\
\text { dextrins } \\
\text { content, \% } \\
\text { to DS * }\end{array}$} \\
\hline & $\begin{array}{l}\text { amylodex- } \\
\text { trins }\end{array}$ & $\begin{array}{l}\text { erythro- } \\
\text { dextrins }\end{array}$ & $\begin{array}{l}\text { malto- and } \\
\text { achro-dex- } \\
\text { trins }\end{array}$ & \\
\hline $\begin{array}{l}\text { Wheat bread } \\
\text { (without } \\
\text { additives) }\end{array}$ & 0,826 & 0,349 & 0,743 & 1,918 \\
\hline $\begin{array}{l}\text { Wheat } \\
\text { bread with } \\
\text { improver }\end{array}$ & 1,024 & 0,406 & 1,008 & 2,438 \\
\hline
\end{tabular}

Note: * DS - dry substances

It was found that in wheat bread from the improver, a significant increase in dextrins is observed. So the total content of dextrins in wheat bread is $1.918 \%$ to DS, and in wheat bread from an improver $-2.438 \%$ to DS. That is, an increase in dextrins occurs by $27.1 \%$ compared to the control, due to the introduction of maltogenic $\alpha$-amylase and maltodextrin directly with the complex bakery improver "Freshness CDP SUPER".

The consumer value of bakery products depends on microbiological indicators, namely the presence of molds. A study was carried out to determine the microbiological parameters of prototypes of products after 4 hours of cooling and 72 hours of storage. The research results are presented in Table 7.

Table 7

Microbiological indicators of experimental bread samples, $n=3, p \leq 0.95$

\begin{tabular}{|c|c|c|c|c|}
\hline \multirow{2}{*}{$\begin{array}{c}\text { Microbiologi- } \\
\text { cal indicators, } \\
\mathrm{CFU} / \mathrm{g}\end{array}$} & \multicolumn{2}{|c|}{ Wheat bread (control) } & \multicolumn{2}{|c|}{$\begin{array}{l}\text { Wheat bread with } \\
\text { improver }\end{array}$} \\
\hline & $\begin{array}{l}4 \text { hours af- } \\
\text { ter baking }\end{array}$ & $\begin{array}{c}72 \text { hours } \\
\text { after baking }\end{array}$ & $\begin{array}{l}4 \text { hours af- } \\
\text { ter baking }\end{array}$ & $\begin{array}{c}72 \text { hours } \\
\text { after baking }\end{array}$ \\
\hline QMAFAnM & $1.4 \times 10^{3}$ & $4.0 \times 10^{3}$ & $2.0 \times 10^{3}$ & $3.1 \times 10^{3}$ \\
\hline $\begin{array}{c}\text { LAB Lactic } \\
\text { acid bacteria }\end{array}$ & $<10^{3}$ & $<10^{3}$ & $<10^{3}$ & $<10^{3}$ \\
\hline Yeast & $<100$ & $<100$ & $<100$ & $<100$ \\
\hline mold fungi & $<100$ & $0.1 \times 10^{2}$ & $<100$ & $1.0 \times 10^{2}$ \\
\hline $\begin{array}{l}\text { Spore-form- } \\
\text { ing bacteria }\end{array}$ & $9.0 \times 10^{2}$ & $10.0 \times 10^{2}$ & $7.2 \times 10^{2}$ & $8.2 \times 10^{2}$ \\
\hline $\begin{array}{c}\text { Escherichia } \\
\text { coli bacteria } \\
\text { (round } \\
\text { shape) } \\
\end{array}$ & $\mathrm{n} / \mathrm{d}$ & $\mathrm{n} / \mathrm{d}$ & $\mathrm{n} / \mathrm{d}$ & $\mathrm{n} / \mathrm{d}$ \\
\hline $\begin{array}{c}\text { Rotten bac- } \\
\text { teria }\end{array}$ & $<10^{3}$ & $<10^{3}$ & $<10^{3}$ & $<10^{3}$ \\
\hline $\begin{array}{c}\text { Leuconostoc } \\
\text { bacteria }\end{array}$ & $<10^{3}$ & $<10^{3}$ & $<10^{3}$ & $<10^{3}$ \\
\hline
\end{tabular}

From the Table 7, it can be seen that during storage of wheat bread from the improver for 72 hours, the amount of QMAFAnM is less than in the control. Mold fungi and spore-forming bacteria in wheat bread with an improver contain less than control, than after 4 hours and 72 hours of storage. So, according to microbiological indicators, wheat bread from an improver has lower indicators compared to wheat bread, which is proof of the preservation of the freshness of finished products.

\section{Discussion of the results of the development and use of the complex bakery improver "Freshness CDP SUPER"}

To improve the quality of baked goods, manufacturers apply various technological measures and/or use food additives and various ingredients. In the process of bread production, various technological problems can arise, therefore, manufacturers use several food additives with different definitions to quickly solve the problem. Their dosage is very small, therefore, overdose is often observed, especially if more than one food supplement is used. This prompted the production of complex bakery improvers with targeted action, which is achieved by a variety of compositions. They consist of a functional base and an active part. The functional base can be flour, starch, dry wheat raw materials, non-traditional raw materials for bakery products. They include various ingredients of the baking industry and food additives, which leads to a wide range of complex bakery improvers [7, 10, 11]. 
The formulation of a complex bakery improver of directional action "Freshness CDP SUPER" has been developed. The research results are given in Table 2, the expediency of using as a functional basis - whey protein concentrate dry "CDP-UV-65" is substantiated. In the results of determining the complex quality indicator, the optimal dosage of the prescription ingredients of the active part of the improver was established (Table 3). The active part included: the enzyme preparation Novamil $1500 \mathrm{MG}$, dry wheat gluten, carboxymethyl cellulose, apple pectin, maltodextrin, lecithin, ascorbic acid.

According to the research results (Table 4), it is found that the developed improver is intended to intensify the technological process, namely, to replace the fermentation process $(210 \mathrm{~min}$.) on the curing process (30 $\mathrm{min}$.) and slow down the staling process.

It is found that the use of the complex bakery improver "Freshness CDP SUPER" in the technology of bread made from wheat flour helps to reduce the duration of the technological process by three times. This is due to the use of an amylolytic enzyme in the improver, maltodextrin and the addition of additional nitrogenous nutrition for yeast together with CDP, which contributes to the intensification of the fermentation process. The prolongation of freshness is due to the introduction of animal and vegetable proteins into bakery products with a complex bakery improver, which makes the structure of the crumb pores stronger due to the strengthening of hydration bonds. Due to this, the loss of moisture by the starch during storage is suppressed. The action of the enzyme preparation reduces the rate of recrystallization of the amylopectin fraction of starch, delays its retrogradation, that is, the return of moisture during aging [17]. Also, along with the improver, water-retaining additives are introduced into the products, namely maltodextrin, carboxymethyl cellulose, apple pectin, which during storage of the products contain osmotically and adsorbed moisture [23].

Studies have found that the crumbling of wheat bread when using the developed improver is less compared to wheat bread, that is, the products know less moisture (Fig. 1). This is achieved through the use of carboxymethyl cellulose, which contributes to the retention of water in bread during storage due to its high water-clay capacity, which is 40 times greater than that of wheat flour [15]. Also, the use of maltodextrin, which is a water-soluble hydrocolloid, increases the degree of moisture retention due to the formation of a three-dimensional network, which inhibits the interaction of gluten and starch, as a result of which starch retrogradation slows down [19,24].

As a result of aging of bread biopolymers, osmotically and adsorptively bound moisture is released, as a result of which moisture redistribution into micropores. Thus, the number of pores increases. The micrographs (Fig. 2) show that in bread with the improver there are very few layers of air in comparison with the control sample.

As a result of the action of the developed improver in the products, there is an increase in low-molecular-weight dextrins, namely maltodextrin and achrodextrin, by $35.6 \%$ compared to the control, Table 6 . Due to this, the process of staling of bakery products is slowed down due to the formation of a three-dimensional network by low-molecular dextrins, which prevents the interaction of gluten and starch and the release of moisture by starch [24].
After baking, the crust of bread is almost sterile, but the products inside are warmed up only to a temperature of $93 \ldots 98^{\circ} \mathrm{C}$, in connection with which a certain amount of bacterial spores and vegetative cells remains [22, 25]. During the study of prototypes for microbiological indicators of quality, it was established (Table 7) that during storage for 72 hours the amount of QMAFAnM is less than in the control, the amount of molds increases within the margin of error. Thus, the use of the developed complex bakery improver "Freshness CDP SUPER" in wheat bread technology reduces the microbiological index, which is evidence of an increase in the stability of finished products during storage.

Thus, the use of complex bakery bread made from wheat flour made by accelerated technologies is not packaged for up to 72 hours of storage.

However, the effect of the complex bakery improver "Freshness CDP SUPER" on the mechanism of glass transition of starch products during storage remains unclear.

Further research on this topic will concern the establishment of the effect of the complex bakery improver "Freshness CDP SUPER" on the structural, mechanical and colloidal properties of the dough.

\section{Conclusions}

1. Prescription ingredients for the development of a complex bakery improver with directional action are selected. A recipe for a complex bakery improver "Freshness CDP SUPER" has been developed, the use of which intensifies the technological process of making bread from wheat flour and prolongs the freshness of finished products up to 72 hours of storage unpackaged. CDP is chosen as the functional basis, the active part included: the enzyme preparation Novamil 1500 MG (Denmark), dry wheat gluten, carboxymethyl cellulose, apple pectin, maltodextrin, lecithin, ascorbic acid.

2. It is found that the use of rational dosing of the complex bakery improver "Freshness CDP SUPER" in the amount of $1.5 \%$ to the flour mass by accelerated technology leads to a reduction in the technological process by 180 minutes. Despite the removal of the fermentation process, the products made from the improver are characterized by better organoleptic characteristics, a large specific volume, better dimensional stability and porosity compared to the control.

3. The use of rational dosage of the developed complex bakery improver "Freshness CDP SUPER" extends the shelf life up to 72 hours unpackaged. This is confirmed by an increase in the total deformation of the crumb by $47 \%$ compared to the control. In the crumb of wheat bread from the improver, there is a decrease in the number of layers of air and more by $25 \%$ compared with the control, the accumulation of dextrins.

\section{Acknowledgement}

This work is supported by a grant from the Ministry of Education and Science of Ukraine "Scientific substantiation of resource-efficient technologies for food products enriched with polyfunctional ingredients" (state registration No. 0120U102556). 


\section{References}

1. Vasylchenko, O. M. (2019). Khlibopekarska promyslovist Ukrainy. Syrovynne zabezpechennia ta perspektyvy yii rozvytku. Materialy mizhnarodnykh naukovo-praktychnykh konferentsiy «Innovatsiyni tekhnolohiyi u vyrobnytstvi» ta «Zdobutky ta perspektyvy rozvytku kondyterskoi haluzi». Kyiv:NUKhT, 20-22. Available at: http://dspace.nuft.edu.ua/jspui/bitstream/123456789/30942/1/ confectionery.pdf.pdf

2. Lebedenko, T., Kozhevnikova, V., Kotuzaki, O., Novichkova, T. (2019). Determining the efficiency of spontaneous sourdough for stabilizing the quality of bread products in bakeries and catering enterprises. Eastern-European Journal of Enterprise Technologies, 4 (11 (100)), 22-35. doi: https://doi.org/10.15587/1729-4061.2019.174289

3. Pashchenko, L. P., Zharkova, I. M. (2014). Tehnologiya hlebopekarnogo proizvodstva. Sankt-Peterburg: Lan', 672. Available at: https://e.lanbook.com/book/45972

4. Starovoytova, O. V., Kurlyanova, V. N., Kilyakov, E. L., Mingaleeva, Z. Sh. (2012). Vliyanie kompleksnogo uluchshitelya na hlebopekarnye svoystva muki i brodil'nuyu aktivnost' drozhzhey. Vestnik Kazanskogo tehnologicheskogo universiteta, 14, 196 198. Available at: https://cyberleninka.ru/article/n/vliyanie-kompleksnogo-uluchshitelya-na-hlebopekarnye-svoystva-muki-ibrodilnuyu-aktivnost-drozhzhey

5. Yaroshevych, T. S., Yaroshevych, O. M. (2013). Suchasni tendentsiyi u formuvanni yakosti khlibobulochnykh vyrobiv. Tovaroznavchyi visnyk, 6, 258-262. Available at: http://tovvisnik.lutsk-ntu.com.ua/index.php/tovvisnik/issue/view/3/2

6. Bilyk, O., Bondarenko, Y., Kochubei-Lytvynenko, O., Khalikova, E., Fain, A. (2019). Studying the effect of the integrated bread baking improver "Mineral Freshness Super" on consumer properties of wheat bread. Eastern-European Journal of Enterprise Technologies, 2 (11 (98)), 65-72. doi: https://doi.org/10.15587/1729-4061.2019.162671

7. Bilyk, O. (2017). Development of complex bakery improving agents for bakery products of extended shelf life. Scientific Works of National University of Food Technologies, 23 (5 (2)), 239-247. doi: https://doi.org/10.24263/2225-2924-2017-23-5-1-27-23-5-2-30

8. Generally Recognized As Safe. Available at: https://de.wikipedia.org/wiki/Generally_Recognized_As_Safe

9. Generally Recognized as Safe (GRAS). Available at: https://www.fda.gov/food/food-ingredients-packaging/generally-recognizedsafe-gras

10. Zyuzko, A. S., Korostova, E. V., Bondarenko, V. I. (2011). Working out complex improvers for improvement of bread quality from wheat flour. Izvestiya vysshih uchebnyh zavedeniy. Pishchevaya tehnologiya, 4, 24-25. Available at: https://cyberleninka.ru/ article/n/razrabotka-kompleksnogo-uluchshitelya-dlya-povysheniya-kachestva-hleba-iz-pshenichnoy-muki

11. Korshenko, L. O. (2014). Stabilization of wheat bread's quality with low baking properties. On-line Journal "Naukovedenie", 6. doi: https://doi.org/10.15862/115tvn614

12. Korshenko, L. O., Chizhikova, O. G., Tanashkina, T. V., Dotsenko, S. M., Abdulaeva, N. N., Semenyuta, A. A. (2014). Substantiation of using buckwheat malt during baking improver development. Tehnika i tehnologiya pishchevyh proizvodstv, 1, 49-53. Available at: https://cyberleninka.ru/article/n/obosnovanie-ispolzovaniya-grechnevogo-soloda-pri-razrabotke-kompozitsii-hlebopekarnogouluchshitelya

13. Lambert-Meretei, A., Szendrei, E., Nogula-Nagy, M., Fekete, A. (2010). Methods to evaluate the effects of bread improver additive on bread crumb texture properties. Acta Alimentaria, 39 (2), 180-191. doi: https://doi.org/10.1556/aalim.39.2010.2.10

14. Gómez, M., del Real, S., Rosell, C. M., Ronda, F., Blanco, C. A., Caballero., P. A. (2004). Functionality of different emulsifiers on the performance of breadmaking and wheat bread quality. European Food Research and Technology, 219 (2), 145-150. doi:https://doi.org/ 10.1007/s00217-004-0937-y

15. Curti, E., Carini, E., Tribuzio, G., Vittadini, E. (2014). Bread staling: Effect of gluten on physico-chemical properties and molecular mobility. LWT - Food Science and Technology, 59 (1), 418-425. doi: https://doi.org/10.1016/j.lwt.2014.04.057

16. Ammar, A.-F., Siddeeg, A., Aqlan, F. M., Howladar, S. M., Refai, M. Y., Afifi, M. et. al. (2020). Shelf life extension of wheat bread by alhydwan flour and Carboxymethylcellulose and improvement of their quality characteristics, dough rheological and microstructure. International Journal of Biological Macromolecules, 156, 851-857. doi: https://doi.org/10.1016/j.ijbiomac.2020.04.023

17. Zhang, L., Li, Z., Qiao, Y., Zhang, Y., Zheng, W., Zhao, Y. et. al. (2019). Improvement of the quality and shelf life of wheat bread by a maltohexaose producing $\alpha$-amylase. Journal of Cereal Science, 87, 165-171. doi: https://doi.org/10.1016/j.jcs.2019.03.018

18. Imeson, A. (Ed.) (2010). Food Stabilisers, Thickeners and Gelling Agents. Wiley-Blackweel, 368. Available at: https:// www.wiley.com/en-us/Food+Stabilisers\%2C+Thickeners+and+Gelling+Agents-p-9781405132671

19. BeMiller, J., Whistler, R. (Eds.) (2009). Starch: chemistry and technology. Academic Press, 894. Available at: https:// www.elsevier.com/books/starch/bemiller/978-0-12-746275-2

20. Lebedenko, T. Ye., Pshenyshniuk, H. F., Sokolova, N. Yu. (2014). Tekhnolohiya khlibopekarskoho vyrobnytstva. Praktykum. Odessa: «Osvita Ukrainy», 392.

21. Drobot, V. I. (Ed.) (2015). Tekhnokhimichnyi kontrol syrovyny ta khlibobulochnykh i makaronnykh vyrobiv. Kyiv: NUKhT, 902.

22. Hrehirchak, N. M. (2009). Mikrobiolohiya kharchovykh vyrobnytstv. Laboratornyi praktykum. Kyiv: NUKhT, 302.

23. Correa, M. J., Pérez, G. T., Ferrero, C. (2011). Pectins as Breadmaking Additives: Effect on Dough Rheology and Bread Quality. Food and Bioprocess Technology, 5 (7), 2889-2898. doi: https://doi.org/10.1007/s11947-011-0631-6

24. BeMiller, J. N. (2009). One Hundred Years of Commercial Food Carbohydrates in the United States. Journal of Agricultural and Food Chemistry, 57 (18), 8125-8129. doi: https://doi.org/10.1021/jf8039236

25. Pateras, I. M. C. (1998). Bread spoilage and staling. Technology of Breadmaking, 240-261. doi: https://doi.org/10.1007/ 978-1-4615-2199-0_10 